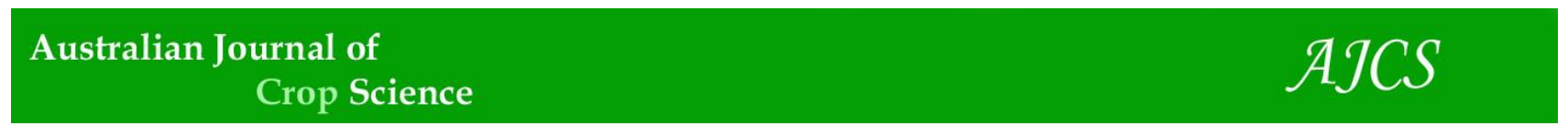

AJCS 14(10):1645-1653 (2020)

ISSN:1835-2707

doi: 10.21475/ajcs.20.14.10.p2447

\title{
Effects of photoperiod, potassium, and growth regulators on micropropagation of Ocimum basilicum L. 'Genovese'
}

\author{
Vanessa F. F. Welz', Jéssica R. Trettel', Andressa B. Nascimento² ${ }^{2}$ Leticia N. Barbosa² ${ }^{2}$ Hélida M. \\ Magalhães'
}

'Programs in Biotechnology Applied to Agriculture, Paranaense University, Mascarenhas de Moraes Square, 4282, 87502-210 Umuarama, Paraná, Brazil

${ }^{2}$ Paranaense University, Umuarama, Mascarenhas de Moraes Square, 4282, 87502-210 Umuarama, Paraná, Brazil

\section{*Corresponding author: helidamara@prof.unipar.br}

\begin{abstract}
Medicinal plants are important in the pharmaceutical, cosmetic, and food industry owing to the diversity of their chemical composition. Basil (Ocimum basilicum L.) is a medicinal plant that is frequently used to produce cosmetics and food. However, the effects of factors such as photoperiod, growth regulators, and nutrients on growth during micropropagation are not comprehensively understood. The objective of this study was to assess the effect of different photoperiods and growth regulators on in-vitro growth and biochemical activity of the $O$. Basilicum 'Genovese' cultivated using a potassium-supplemented culture medium. The experiments were carried out in a completely causalized design and were conducted using a Murashige and Skoog culture medium plus sucrose and agar. In the first experiment, seeds were inoculated at three different photoperiods in the presence or absence of growth regulators. In the second experiment, growth media containing five different concentrations of potassium iodide $(\mathrm{KI})(0,25,50,75$, and $100 \mu \mathrm{M})$ were used. Basil seedlings grown at photoperiods of $16 \mathrm{~h}$ and $24 \mathrm{~h}$ produced more leaves and larger length and shoot mass, and addition of growth regulators showed no effect. However, the root systems produced the highest average values at a photoperiod of $16 \mathrm{~h}$ and when growth regulators were supplemented $(0.23 \mathrm{~g} \pm 0,08)$. Antioxidant activity and the concentration of ascorbate peroxidase were higher under the $16 \mathrm{~h}$ light treatment and with addition of growth regulators. Addition of potassium to the growth medium had no beneficial effects on seedlings. Antioxidant activity was not affected by potassium concentrations, but it remained high (above 13.5\%) when compared with the previous treatment. Catalase activity was the highest in seedlings grown at the highest concentrations of KI. The catalase enzyme is considered a stress indicator, so in higher concentrations of $\mathrm{KI}$ there is evidence that the basil plants may have had oxidative damage.
\end{abstract}

Keywords: antioxidants, basil, Catalase, Lamiaceae, luminosity.

Abbreviations: \% SRL_ free radical sequestration; APX_ Ascorbate peroxidase;BAP_6-benzylaminopurine; BOD_biochemical oxygen demand; $\mathrm{Ca}_{-}$calcium;CAT_Catalase; $\mathrm{CL}_{\text {_ }}$ chlorophyll; DMS_dry mass shoots; DPPH_diphenyl-1-picrylhydrazyl; DRM_dry root mass; FMS_fresh mass shoots; FRM_ fresh root mass; $\mathrm{K}_{-}$potassium; KI_ potassium iodide; LS_ length of shoots; Mg_ magnesium; MS_medium Murashige and Skoog; N_nitrogen; NAA_ $\alpha$-naphthaleneacetic acid; NBT_ nitroblue tetrazolium; NL_ Number of leaves; NS_ Number of shoots; P_ phosphorus; SISVAR 5.6_computer statistical analysis system; SOD_ Superoxide dismutase.

Introduction

Plant tissue culture is a biotechnological technique that facilitates growing of plants in culture media under controlled conditions to produce seedlings in a short amount of time and at high propagation rates (George et al., 2008). Furthermore, this method allows the production of pathogen-free plants of high and standardized quality (Cassells, 2012). Medicinal plants have pharmaceutical properties and have been consumed as natural remedies over millennia (Makri and Kintzios, 2008). More recently, with the advance of chemistry, biochemistry, and techniques for determining chemical compounds, medicinal plants have been used more frequently by the pharmaceutical, cosmetic, and food industry (Alvarez, 2014).
Ocimum basilicum is a medicinal plant of the family Lamiaceae and has antioxidant, antimicrobial, and antitumor properties (Suppakul et al., 2003; Hussain et al., 2008; Mahmoud, 2013; Tenore et al., 2017) owing to the presence of a variety of chemical compounds such as phenylpropanoids, terpenoids, and rosmarinic acid (Trettel et al., 2017; Pagano et al., 2018). The genus Ocimum comprises about 50-60 species with different chemical and morpho- logical characteristics (Makri and Kintzios, 2008). One example is the cultivar 'Genovese', which has large leaves with a leaf area of more than $300 \mathrm{~cm}^{2}$ in a mature plant, and therefore a considerable amount of biomass accumulates in the leaves (Furlan et al., 2013). 
Advances in cultivation techniques and propagation of medicinal plants have not occurred at the same speed as in the industrial sector, and information is lacking regarding factors such as cultivar choice, pest control, diseases, and plant spacing (Makri and Kintzios, 2008; Ncube et al., 2012). Particularly regarding micropropagation, very few protocols have been developed, and the existing studies are inconclusive. This problem also concerns micropropagation of members of the family Lamiaceae, particularly of the genus Ocimum. When propagation protocols are established, typically growth medium components such as macro- and micronutrients, growth regulators, sugars, and others are examined. Plant organogenesis after propagation, however, depends on three crucial factors: genetics, culture medium components, and physical growth medium (George et al., 2008).

Growth medium composition affects plant physiology and morphology, particularly if the used compounds in their respective concentrations cause stress, which may result in an increase or decrease of secondary compounds and oxidative damage (Gill and Tuteja et al. 2010), which may severely damage the explants (Matkowski, 2008). Cytokinins and auxins are the most frequently used growth regulators for tissue culture, and they can influence both plant morphology and growth responses such as shoot and root emission (Motte et al., 2014). Regarding macronutrients, potassium is particularly important for the functioning of various enzymes, maintaining the homeostatic equilibrium, and opening and closing of the stomata (Amtmann and Armengaud, 2009).

The factor 'growth conditions' typically comprises the physical factors that seedlings are exposed to, including temperature, humidity, photoperiod, spectral light range, and light intensity (George et al., 2008). The term photoperiod indicates the amount of time per day during which plants are exposed to light (Adams and Langton, 2005). In an in-vitro environment, effective photosynthesis can be reduced, however, light is essential and plant cells contain proteins termed phytochromes which respond to light and thereby trigger physiological and biochemical responses (Adams and Langton, 2005).

Growth chamber light is typically produced by LED lamps, which causes substantial energetic costs for laboratories and companies that produce seedlings through micropropagation; thus, optimization of the photoperiod may help reduce the costs of micropropagation (Adams and Langton, 2005; George et al., 2008). Furthermore, it is not comprehensively understood how the photoperiod affects the biochemical activity of medicinal plants, particularly regarding antioxidant enzymes including free radical scavengers such as superoxide dismutase (SOD), ascorbate peroxidase (APX), and catalase (CAT) (Gill and Tuteja 2010) and antioxidant compounds (Matkowski, 2008). These aspects have been studied in some depth under conventional cultivation regimes (Adams and Langton, 2005), however, studies under in-vitro conditions are scarce. Photoperiod and addition of potassium and growth regulators likely affect $O$. basilicum growth, which may help produce plants of high physiological quality (Jo et al., 2008). Moreover, these factors may be expected to affect the function of antioxidant mechanisms in $O$. basilicum plants, and we predicted that the activity of enzymes and chemical compounds should increase in treatments that cause more damage to the seedlings. The objective of this study was to evaluate in-vitro growth and biochemical activity in $O$. basilicum 'Genovese' supplemented with potassium at different photoperiods and with different amounts of growth regulators.

\section{Results and Discussion}

\section{Photoperiod and growth regulators}

The interaction of culture medium and photoperiod affected the assessed characteristics. The amount of produced leaves increased by approximately $50 \%$ in plants grown in media without growth regulators and in seedlings grown under 16 $h$ of light (T3; Table 2). Seedling length and dry and fresh mass increased in plants grown without regulators and with $24 \mathrm{~h}$ and $16 \mathrm{~h}$ light (T3 and T1, respectively; Table 2). However, for the growth of the root system, addition of growth regulators was beneficial mainly in T5 and T6 (Table 2). Callus formation which is common in plants of the Lamiaceae family was observed in all treatments with growth regulators, and the highest average values were observed in treatments T5 and T6 (Table 2). The number of shoots and the chlorophyll index were not influenced by any of the assessed factors.

We observed a substantial increase in the production of new leaves in $O$. basilicum 'Genovese' seedlings grown at $16 \mathrm{~h}$ of light. The prediction that addition of growth regulators should increase this effect was not confirmed. The amount of leaves is particularly important in in-vitro production of basil because leaves contain essential oil-producing glands, which is of interest to the industry (Zuzarte et al., 2010; Amaral-Baroli et al., 2016). Numerous studies have been conducted on the effects of photoperiod on the flowering process; however, the effect of photoperiod on plant growth has received little attention (Adams and Langton, 2005). In the few existing studies the rate of leaf emission as well as the leaf area tended to increase in periods of $16 / 8$ or $12 / 12$ (Vaillant et al., 2005; Jo et al., 2008). According to Adams and Langton (2005), the increase in the photoperiod should promote an increase in meristematic activity at the apex of shoots, which would promote leaf growth. However, its continuous activity may lead to photo-oxidation, chlorosis, and foliar necrosis (Velez-Ramirez et al., 2011).

With $24 \mathrm{~h}$ light, $O$. basilicum 'Genovese' leaves increased in length, suggesting increased production of gibberellins. However, in Chrysanthemum morifolium Ramat. 'Ellen', the same treatment led to a reduction in branch length (Kurilčik et al., 2008). Increased shoot biomass production in treatments T1 and T3 may be due to a higher frequency of cell divisions caused by an optimum of endogenous hormone concentrations (Motte et al., 2014). Exogenous supplementation with growth regulators substantially reduced the biomass increment, which was more severe in plants grown at longer photoperiods. If not metabolized by the plant, growth regulators exert adverse and toxic effects (Motte et al., 2014). Correspondingly, the dry weight of $C$. morifolium Ramat. 'Ellen' increased more than twice at photoperiods of $16 \mathrm{~h}$ (Kurilčik et al., 2008).

In the root system of basil plants, $8 \mathrm{~h}$ of light and growth regulator supplementation increased root mass, which was likely due to the beneficial effects of auxins that elicit formation of lateral roots (Fukaki and Tasaka, 2009; Motte et al., 2014). Similar effects of the photoperiod on auxins were observed in Plumbago zeylanica L. (Saxena et al., 2000). 
The amount of absorbed $\mathrm{N}$ differed substantially between shoots and roots; on average, shoots contained $30 \%$ more $\mathrm{N}$, regardless of treatment (Table 3). TreatmentsT4 (64.40 g.Kg $\left.{ }^{1} \pm 0.21\right)$ and T6 $\left(58.06\right.$ g. Kg $\left.^{-1} \pm 5.23\right)$ showed the highest $\mathrm{N}$ uptake rates in shoots, and treatments T2 (45.90 g. Kg ${ }^{-1} \pm$ 0.49 ) and T4 (41.34 g. $\mathrm{Kg}^{-1} \pm$ 7.73) showed the highest amount of $\mathrm{N}$ in roots (Table 3). $\mathrm{P}$ was higher in treatments T3 (3.17 g. Kg $\left.{ }^{-1} \pm 0.57\right)$ and T4 $\left(2.63 \mathrm{~g} . \mathrm{Kg}^{-1} \pm 0.09\right)$ than in the other treatments, in both shoots and roots (Table 3 ).

Antioxidant activity was substantially increased in treatment T6 (17.29 \pm 4.48$)$, whereas no significant difference was observed among the other treatments (Table 4). Antioxidant activity in $O$. basilicum 'Genovese' may be related to two factors: 1) stress caused by the treatments, or 2) an elicitation factor (Patel and Krishnamurthy, 2013; Alvarez, 2014). If culture medium and photoperiod cause stress, one of the defense mechanisms of plants is to increase the production of secondary metabolites which can oxidize free radicals that otherwise damage lipids, proteins, and nucleic acids (Noctor et al., 2018). An increase in antioxidant activity by more than $60 \%$ (T6) compared to T3 indicated increased production of secondary metabolites to mitigate damage caused by free radicals.

Plants of the genus Ocimum, and particularly basil, are known to produce terpenoids such as linalool (Trettel et al., 2017) and phenylpropanoids such as eugenol and methyl eugenol (Trettel et al., 2017; Trettel et al., 2018b), and they can also produce several phenolic acids such as rosmarinic acid (Kiferle et al., 2013; Pagano et al., 2018). Antioxidant capacity of all of these compounds has been shown previously (Javanmardi et al., 2003; Tenore et al., 2017); therefore, it is possible that these compounds mitigated the respective effects in T6, which would explain the higher activity observed in this treatment.

The functions of antioxidant enzymes have been studied indepth in plants under natural conditions (Demidchik, 2015; Noctor et al., 2018); however, less is known about their functions in in-vitro environments and under different photoperiods. Understanding these mechanisms may help increase plant productivity. The results of these assays showed variable responses depending on the treatment. APX concentration was higher in T6 $(1.5 \mathrm{mM})$, whereas enzyme concentration was similar among the other treatments and was below $0.2 \mathrm{mM}$ (Fig. 1A); CAT concentration was highest in the $\mathrm{T} 2$ and $\mathrm{T} 5$ treatments (above $0.3 \mathrm{mM}$; Fig.1B). SOD activity was highest activity, except in T6, the average of the other treatments was above 250 U (Fig.1C).

In line with antioxidant activity, APX activity increased eightfold in treatment T6, compared with the other treatments. This enzyme is part of the second phase of free radical scavenging and catalyzes $\mathrm{H}_{2} \mathrm{O}_{2}$ to water using ascorbate as an electron donor (Demidchik, 2015; Noctor et al., 2018). Interestingly, APX did not exceed $0.35 \mathrm{mM}$ (Fig.1.B) in any other treatment, and APX activity was 4.5-times higher than those of CAT. CAT and APX concentration were approximately $0.2 \mathrm{mM}$, each, in all other treatments.

The functions of antioxidant enzymes have been studied indepth previously (Demidchik, 2015; Noctor et al., 2018); however, optimal timing and enzymatic succession in plants remains unknown and is very difficult to examine because processes in plant cells are dynamic and occur synchronously. Plants have several antioxidant mechanisms to promote free radical scavenging (Ahanger and Agarwal,
2017). Determining which pathway is the most important one in any given situation is not straightforward because this may depend on other metabolic processes that are ongoing at that moment (Aghaei et al., 2009). As an example of this phenomenon, APX concentration in Melissa officinalis L. plants subjected to different $\mathrm{NaCl}$ concentrations (0-200 $\mathrm{mM}$ ) was not affected by the treatment, whereas CAT increased to up to $150 \mathrm{mM}$ after a near-50\% decrease (Bonacina et al., 2017), and SOD increased in seedlings treated with 150 and $200 \mathrm{mM} \mathrm{NaCl}$. In this case, the most important enzyme appeared to be CAT followed by SOD, as both enzymes seemed to neutralize free radicals, along with other mechanisms. Taken together, antioxidant enzyme kinetics also depend on other metabolic processes.

\section{Supplementation with $\mathrm{Kl}$ in culture medium}

Potassium is an important macronutrient as it is a co-factor of several enzymes; it is required in the processes of plant cell osmoregulation (Amtmann and Armengaud, 2009), and culture media typically contain a defined amount of $\mathrm{K}$. We predicted that $\mathrm{K}$ supplementation would increase seedling growth, however, excessive amounts of $\mathrm{K}$ may also elicit adverse responses. So far, the concentration of $\mathrm{K}$ in growth media of medicinal plants has received little attention (Silva et al., 2017).

Addition of $\mathrm{K}$ to the culture medium showed no beneficial effect on growth and did not affect the assessed morphological traits. Leaf number and shoot dry mass decreased with increasing $\mathrm{K}$ concentration (Table 5). Length and fresh mass of the shoots, fresh and dry mass of the roots, and the chlorophyll index did not differ significantly between treatments (Table 5). Interestingly, no callus formation was observed in any of the treatments. Similar results were observed after in-vitro cultivation of 0 . basilicum 'Red Rubin' (Silva et al., 2017) and Curcuma longa L. (unpublished data) using similar $\mathrm{KI}$ concentrations as in the present study. Seedlings of Cattleya loddigesii Lindley grown at different concentrations of $\mathrm{K}$ silicate showed an increase in the number of leaves, growth, and shoot mass at concentration of up to $1 \mathrm{mg} . \mathrm{L}^{-1}$ (Alves et al., 2016). According to Amtmann and Armengaud (2009) and Malvi (2011), excess $\mathrm{K}$ affects biosynthesis and metabolic allocation.

Elemental nutrients are absorbed at different velocities, and the presence of one nutrient may inhibit or enhance the rate of absorption of a different nutrient. Inhibition can occur when entry into the root cells takes place via the same site of absorption, resulting in absorption competition or antagonism. Synergistic enhancement typically occurs between nutrients that are absorbed at different sites (Malvi, 2011; Rietra et al., 2017). Regardless of the treatment, the $\mathrm{N}$ was absorbed at greater quantities than $\mathrm{K}$, with $69.25 \%$ absorbed by the shoots and $73.53 \%$ by the roots. Nitrogen uptake showed similar average values in all treatments, apart from treatment $\mathrm{T} 1$ that did not receive additional $\mathrm{K}$ and showed higher $\mathrm{N}$ uptake (48.74 g. Kg ${ }^{-1} \pm$ 4.18). In roots, we observed a trend of $\mathrm{N}$ uptake to increase with increasing concentrations, with a maximum absorption of (47.95 g. Kg $\left.{ }^{-1} \pm 1.10\right)$ at $100 \mu \mathrm{M}$ (Table 6).

Antagonism typically occurs between $\mathrm{Ca}$ or $\mathrm{Mg}$ uptake and $\mathrm{K}$ uptake, as these minerals compete for the same site of absorption (Malvi, 2011); therefore, we predicted a respective effect in seedlings of $O$. basilicum 'Genovese'. Shoot $\mathrm{Ca}$ content, however, was similar among all 
treatments, and root Ca content increased slightly at higher $\mathrm{K}$ concentrations (Table 6). Shoot $\mathrm{Mg}$ content also did not differ significantly between the treatments, and root $\mathrm{Mg}$ content increased at higher $\mathrm{K}$ concentrations (Table 6).

Table 1. Culture medium and photoperiods for growth and biochemical activity 0 . basilicum 'genovese'.

\begin{tabular}{|c|c|c|c|c|c|c|}
\hline & $\begin{array}{c}\text { Treatments } \\
1\end{array}$ & $\begin{array}{l}\text { Treatments } \\
2\end{array}$ & $\begin{array}{c}\text { Treatments } \\
3\end{array}$ & $\begin{array}{c}\text { Treatments } \\
4\end{array}$ & $\begin{array}{l}\text { Treatments } \\
5\end{array}$ & $\begin{array}{c}\text { Treatments } \\
6\end{array}$ \\
\hline MS (\%) & 100 & 100 & 100 & 100 & 100 & 100 \\
\hline $\mathrm{BAP}\left(\mathrm{mg} \cdot \mathrm{L}^{-1}\right)$ & 0.0 & 0.0 & 0.0 & 0.4 & 0.4 & 0.4 \\
\hline NAA $\left(m g \cdot L^{-1}\right)$ & 0.0 & 0.0 & 0.0 & 0.2 & 0.2 & 0.2 \\
\hline Photoperiod & $\begin{array}{l}24 \text { horas } \\
\text { light }\end{array}$ & $\begin{array}{l}\text { 12h light } \\
\text { /12h dark }\end{array}$ & $\begin{array}{l}\text { 16h light } \\
\text { /8h dark }\end{array}$ & $\begin{array}{l}24 \text { horas } \\
\text { light }\end{array}$ & $\begin{array}{c}\text { 12h light } / 12 \mathrm{~h} \\
\text { dark }\end{array}$ & $\begin{array}{c}\text { 16h light /8h } \\
\text { dark }\end{array}$ \\
\hline
\end{tabular}

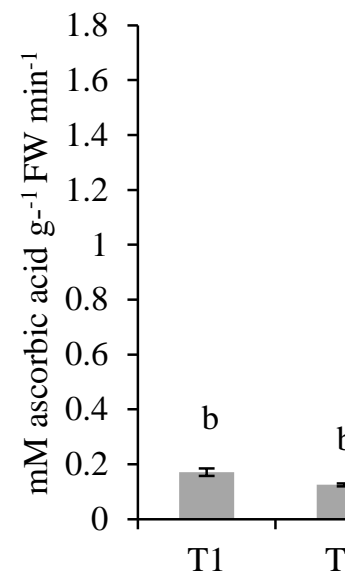

Treatments

Additional $\mathrm{K}$ thus did not negatively affect absorption of $\mathrm{Ca}$ or $\mathrm{Mg}$ in O. basilicum 'Genovese'. Ca deficiency typically manifests as death of the apical egg yolk, chlorosis, and internerval

A
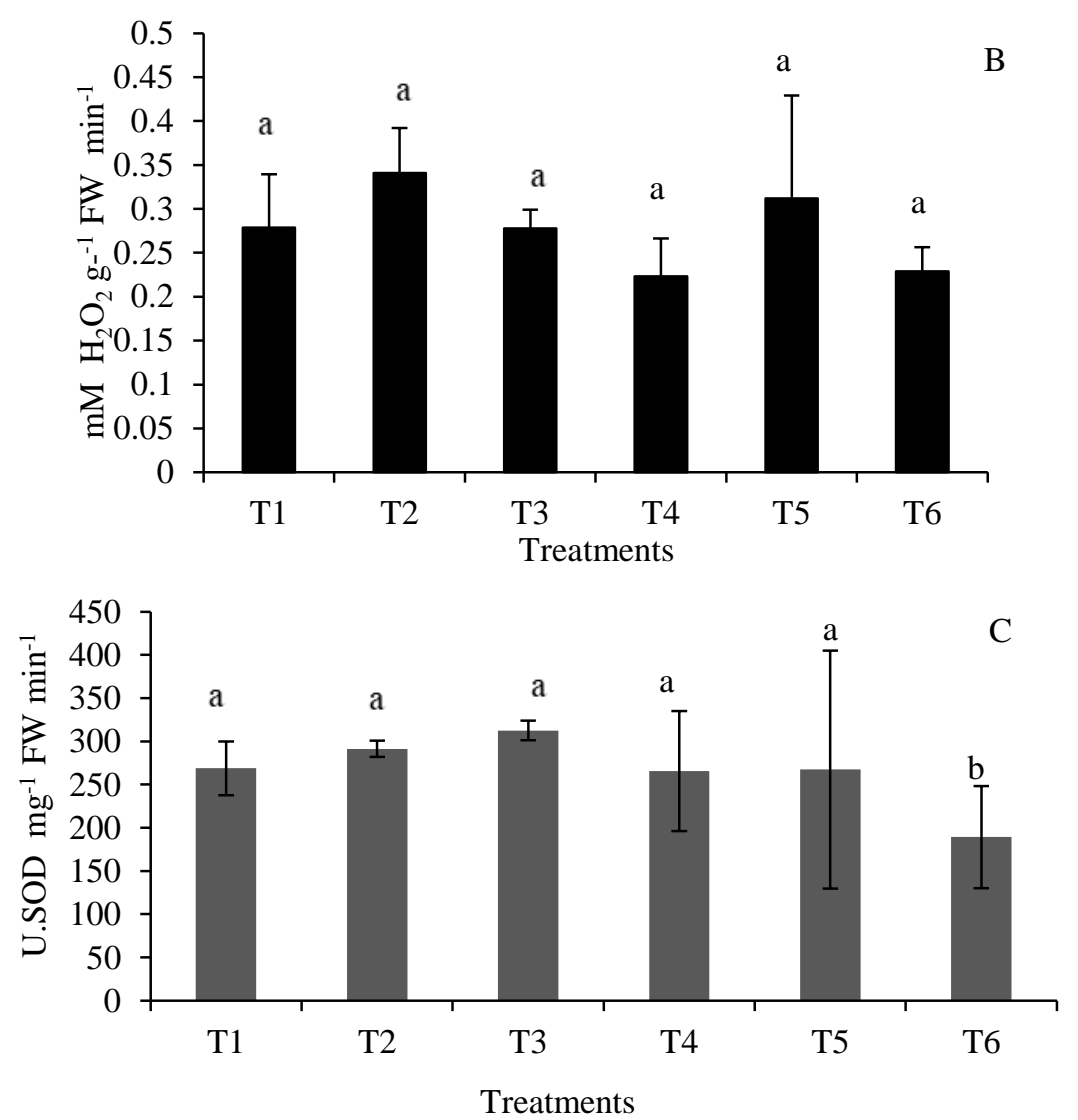
Fig 1. Antioxidant enzymes activity APX (A), CAT (B) and SOD (C) obtained from fresh leaves of $O$. basilicum 'genovese' as a function of different formulations of MS medium and photoperiods. Means followed by the same letter in the column do not differ by Tukey's test 5\%. T1 -24 h light; T2 - 12h light + 12h dark; T3 - 16 h light +8 h dark - (T1: T3 MS 100\%, sucrose 30.0 g. $\mathrm{L}^{-1}$, agar 6.5 g. $\mathrm{L}^{-}$ $\left.{ }^{1}\right)$; T4 -24 h light; T5 - $12 \mathrm{~h}$ light $+12 \mathrm{~h}$ dark; T6 - $16 \mathrm{~h}$ light $+8 \mathrm{~h}$ dark - (T4:T6 MS 100\%, sucrose 30.0 g.L $\mathrm{L}^{-1}$, agar 6.5 g.L $\mathrm{L}^{-1} ;$ BAP 0.4 g.L and NAA 0.2 g.: L $^{-1}$ )

Table 2. Number of leaves (NL), shoots (NS), length of shoots (LS), fresh mass shoots (FMS), dry mass shoots (DMS), fresh root mass (FRM), dry root mass (DRM), callus fresh (CF) and callus dry (CDM) and chlorophyll (CL) of $O$. basilicum 'genovese' as a function of different formulations of MS medium and photoperiods.

\begin{tabular}{cccccc}
\hline Treatments & NL & NS & LS (mm) & FMS (g) & DMS (g) \\
\hline T1 & $16.46 \pm 3.54^{b^{\circ}}$ & $1.00 \pm 0.00^{\mathrm{a}}$ & $61.48 \pm 5.66^{\mathrm{a}}$ & $4.03 \pm 0.68^{\mathrm{ab}}$ & $0.31 \pm 0.03^{\mathrm{a}}$ \\
T2 & $13.27 \pm 2.42^{\mathrm{b}}$ & $0.75 \pm 1.50^{\mathrm{a}}$ & $42.54 \pm 5.88^{\mathrm{b}}$ & $3.12 \pm 0.33^{\mathrm{bc}}$ & $0.23 \pm 0.04^{\mathrm{b}}$ \\
T3 & $24.33 \pm 2.19^{\mathrm{a}}$ & $0.00 \pm 0.00^{\mathrm{a}}$ & $57.52 \pm 1.29^{\mathrm{ab}}$ & $4.40 \pm 0.61^{\mathrm{a}}$ & $0.36 \pm 0.04^{\mathrm{a}}$ \\
T4 & $12.87 \pm 3.45^{\mathrm{b}}$ & $1.50 \pm 1.73^{\mathrm{a}}$ & $53.65 \pm 5.70^{\mathrm{ab}}$ & $1.15 \pm 0.61^{\mathrm{d}}$ & $0.07 \pm 0.03^{\mathrm{c}}$ \\
T5 & $13.13 \pm 3.32^{\mathrm{b}}$ & $1.00 \pm 1.15^{\mathrm{a}}$ & $42.18 \pm 7.01^{\mathrm{b}}$ & $2.21 \pm 0.45^{\mathrm{bc}}$ & $0.12 \pm 0.03^{\mathrm{c}}$ \\
T6 & $12.75 \pm 4.17^{\mathrm{b}}$ & $0.25 \pm 0.50^{\mathrm{a}}$ & $59.11 \pm 13.86^{\mathrm{ab}}$ & $4.67 \pm 0.56^{\mathrm{a}}$ & $0.20 \pm 0.02^{\mathrm{b}}$ \\
\hline Treatments & FRM (g) & DRM (g) & CF (g) & CDM (g) & CL \\
T1 & $3.00 \pm 1.05^{\mathrm{ab}}$ & $0.13 \pm 0.04^{\mathrm{ab}}$ & $0.00 \pm 0.00^{\mathrm{b}}$ & $0.00 \pm 0.00^{\mathrm{c}}$ & $20.43 \pm 2.39^{\mathrm{a}}$ \\
T2 & $1.86 \pm 0.79^{\mathrm{b}}$ & $0.08 \pm 0.03^{\mathrm{b}}$ & $0.00 \pm 0.00^{\mathrm{b}}$ & $0.00 \pm 0.00^{\mathrm{c}}$ & $21.02 \pm 1.40^{\mathrm{a}}$ \\
T3 & $4.30 \pm 0.50^{\mathrm{a}}$ & $0.13 \pm 0.04^{\mathrm{ab}}$ & $0.00 \pm 0.00^{\mathrm{b}}$ & $0.00 \pm 0.00^{\mathrm{c}}$ & $26.71 \pm 2.38^{\mathrm{a}}$ \\
T4 & $3.02 \pm 0.44^{\mathrm{ab}}$ & $0.12 \pm 0.03^{\mathrm{b}}$ & $1.43 \pm 0.98^{\mathrm{b}}$ & $0.10 \pm 0.13^{\mathrm{bc}}$ & $24.11 \pm 1.68^{\mathrm{a}}$ \\
T5 & $4.04 \pm 0.97^{\mathrm{a}}$ & $0.15 \pm 0.04^{\mathrm{ab}}$ & $3.95 \pm 0.46^{\mathrm{a}}$ & $0.21 \pm 0.02^{\mathrm{ab}}$ & $22.16 \pm 3.25^{\mathrm{a}}$ \\
T6 & $3.00 \pm 0.60^{\mathrm{ab}}$ & $0.23 \pm 0.08^{\mathrm{a}}$ & $5.47 \pm 1.19^{\mathrm{a}}$ & $0.25 \pm 0.09^{\mathrm{a}}$ & $21.88 \pm 4.66^{\mathrm{a}}$ \\
\hline
\end{tabular}

* Means followed by the same letter in the column do not differ by Tukey's test $5 \%$

T1 -24 h light; T2 - 12h light + 12h dark; T3 - 16 h light + 8 h dark - (T1: T3 MS 100\%, sucrose 30.0 g.L - $^{-1}$ agar 6.5 g.L - $\left.^{-1}\right) ;$ T4 -24 h light; T5 - 12h light +12 h dark; T6 - 16 h light +8 h dark - (T4:T6 MS 100\%, sucrose 30.0 g.L $^{-1}$; agar6.5 g.L ${ }^{-1}$;BAP 0.4 g.L ${ }^{-1}$ and NAA 0.2 g. L $^{-1}$ ).
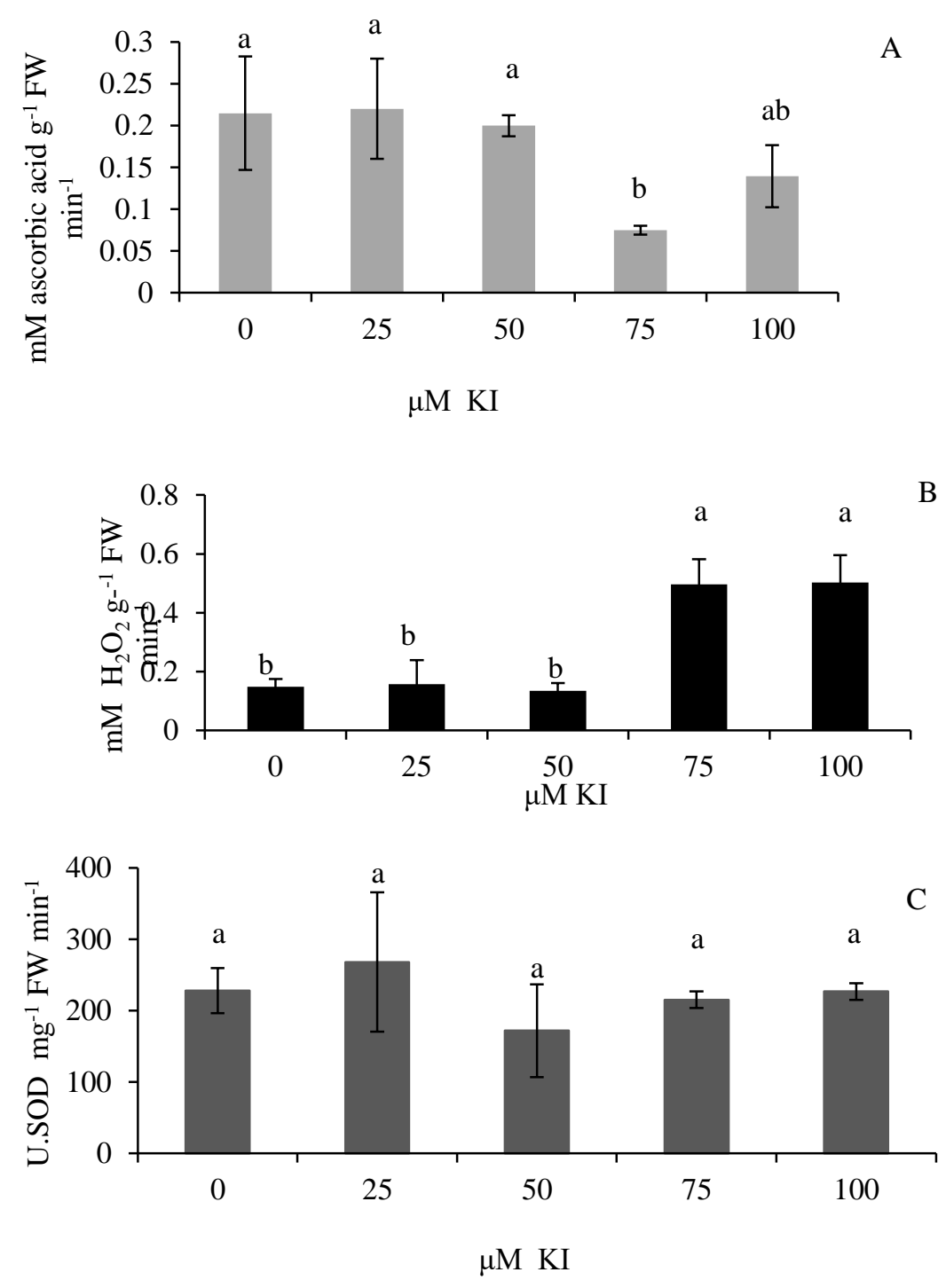
Fig 2. Antioxidant enzymes activity APX (A), CAT (B) and SOD (C) obtained from fresh leaves $O$. basilicum 'genovese' as a function of different potassium iodide (KI) concentrations. Means followed by the same letter in the column do not differ by Tukey's test $5 \%$.

necrosis in new leaves (White and Broadley 2003), and Mg deficiency elicits chlorosis between veins in older leaves with the nerves showing deep green coloration (Guo et al., 2016); however, no signs of $\mathrm{Ca}$ or $\mathrm{Mg}$ deficiency were observed. Any negative responses observed in the treatments were not due to $\mathrm{Ca}$ or $\mathrm{Mg}$ deficiencies, but caused by other metabolic and physiological processes due to excess $\mathrm{K}$.

We previously reported (Experiment 1 ) the importance of determining antioxidant activity in an assay and how this can be used as an indicator of stress. In the present study, however, antioxidant activity was not affected by the treatments (Table 7). The control treatment produced a value of $14.43 \%$ which may be an increase since this medium contained a different growth regulator than the first assay (Alvarez, 2014), or a momentary factor of undetected stress in this treatment. We discussed above the difficulties in understanding the dynamics of free radical control by plant cells as a function of innumerable simultaneous processes that occur within each cell. In this experiment, the response to additional $\mathrm{K}$ caused was different than in the first experiment.

Regarding antioxidant enzymes, responses were affected by the treatments. APX concentrations were above $0.2 \mathrm{mM}$ in the control treatment and in the two treatments with the lowest $\mathrm{KI}$ concentrations (25 and $50 \mu \mathrm{M})$. At $\mathrm{KI}$ concentrations of 75 and $100 \mu \mathrm{M}, \mathrm{APX}$ decreased to values between 0.1 and $0.15 \mathrm{mM}$ (Fig 2A). The response of CAT showed a reversed pattern with the highest $\mathrm{KI}$ concentrations of 75 and $100 \mu \mathrm{M}$ producing higher CAT values of above $0.5 \mathrm{mM}$, with similar values in the other treatments (about $0.15 \mathrm{mM}$; Fig. 2B). SOD activity was below $200 \mathrm{U}$ only in plants cultured in the medium with $50 \mu \mathrm{M} \mathrm{KI}$, whereas $\mathrm{KI}$ concentrations of $25 \mu \mathrm{M}$ increased SOD activity to over $250 \mathrm{U}$ (Fig.2C).

At lower $\mathrm{KI}$ concentrations, APX seemed to be more important as its concentrations doubled in the three lowest $\mathrm{KI}$ concentrations, in contrast to CAT which at $\mathrm{KI}$ concentrations of 75 and $100 \mu \mathrm{M}$ increased four-fold. The elimination of reactive oxygen species by antioxidant enzymes may improve tolerance to agents that cause stress. In seedlings of Triticum aestivum $\mathrm{L}$. subjected to different $\mathrm{K}$ concentrations $\left(0,20,40\right.$, and $\left.60 \mathrm{~kg} \cdot \mathrm{ha}^{-1}\right)$ APX, CAT, and SOD enzyme activity increased, facilitating optimal plant growth (Ahanger and Agarwal, 2017). We therefore suggest that the adverse effects of $\mathrm{KI}$ on $\mathrm{O}$. basilicum 'Genovese' growth did not occur as potential radicals would have been neutralized by antioxidant enzymes.

\section{Materials and Methods}

\section{Seed collection and processing}

The experiments were conducted in the laboratories of Molecular Biology and Plant Tissue Culture of the Paranaense University. Seeds of the cultivar 'Genovese' were obtained from the commercial supplier (Horticeres São Paulo, Brazil)and were subjected to an asepsis procedure using $2 \%$ sodium hypochlorite solution for $15 \mathrm{~min}$ under stirring; the seeds were then washed four times using autoclaved water.

\section{Experiment 1: Growth regulators and photoperiod}

Three different photoperiods and two formulations of Murashige and Skoog culture medium (Murashige and Skoog, 1962) were used (Table 1). All treatments were supplemented with $30 \mathrm{~g} . \mathrm{L}^{-1}$ sucrose and $6.5 \mathrm{~g} . \mathrm{L}^{-1}$ agar (Kasvi Paraná, Brazil), and the $\mathrm{pH}$ was adjusted to 5.8. These treatments were designed based on a previous study (Trettel et al., 2018a).

After preparation of the medium, glass vials containing culture medium were autoclaved at $121{ }^{\circ} \mathrm{C}$ for $20 \mathrm{~min}$ and were then used for seed inoculation which was performed in an aseptic chamber. Four seeds were placed in one flask containing $50 \mathrm{~mL}$ of the culture medium. The flasks were then closed using clear plastic lids and were sealed using PVC film. The flasks were maintained for 80 days at the biochemical oxygen demand (BOD) at $25{ }^{\circ} \mathrm{C}$ and under three different photoperiods: $24 \mathrm{~h}, 12 \mathrm{~h}$, or $16 \mathrm{~h}$. The BOD was equipped with white fluorescent $30-\mathrm{W}$ lamps $84.60 \mu \mathrm{mol}$ $\mathrm{m}^{-2} \cdot \mathrm{s}^{-1}$ (Philips Amsterdam, Netherlands).

\section{Experiment 2: Potassium iodide concentrations}

Seeds subjected to the asepsis treatment were placed in flasks containing Murashige and Skoog medium supplemented with $30 \mathrm{~g} \cdot \mathrm{L}^{-1}$ sucrose, $0.1 \mathrm{mg} \cdot \mathrm{L}^{-1} \quad 6$ Benzylaminopurine (BAP) (Sigma Aldrich Hamburg, Germany), and $6.5 \mathrm{~g}^{-\mathrm{L}^{-1}}$ agar, and the $\mathrm{pH}$ was adjusted to 5.8 . Five concentrations of potassium iodide (KI) were used: 0 , $25,50,75$, and $100 \mu \mathrm{M}$. The cultures were maintained in a growth chamber at $25 \pm 2$ o $\mathrm{C}$ for 80 days. The photoperiod was $24 \mathrm{~h}$, and white fluorescent 20-W lamps (Empalux Curitiba, Brazil) at a light intensity of $72.0 \mu \mathrm{mol} \mathrm{m} \mathrm{m}^{-2} \cdot \mathrm{s}^{-1}$.

\section{Biometric and physiological characteristics}

After 80 days, the following characteristics were assessed in each experiment: leaf number, shoot number, shoot length, fresh shoot mass, shoot dry shoot, total dry mass, fresh mass, dry callus mass, and chlorophyll content. Root length was measured using a digital caliper, and root and shoot dry mass was recorded after drying to constant weight at $65^{\circ} \mathrm{C}$. The chlorophyll index was obtained using a chlorophyll meter (ClorofiLOG ${ }^{\circ}$ model CFL1030; Falker Porto Alegre, Brazil).

\section{Determination of macro - and micronutrients}

Shoots and roots of each treatment were collected at the end of the experiment and were oven-dried to constant weigh tunder air circulation at $65^{\circ} \mathrm{C}$. In plants of experiment 1 , nitrogen $(\mathrm{N})$, and phosphorus $(\mathrm{P})$ were measured. In experiment $2(\mathrm{~N})$ nitrogen, potassium $(\mathrm{K})$, calcium $(\mathrm{Ca})$, and magnesium $(\mathrm{Mg})$ were measured. The samples were sent to the Plant Tissue Laboratory of the University of São Paulo. Nutrient concentrations were measured according to a 
previous study (Malavolta, 1980). All analyses were performed in duplicates.

\section{Analysis of antioxidant activity using a DPPH test}

This analysis was performed 80 days after the start of each experiment. Approximately $0.5 \mathrm{~g}$ of fresh leaves were macerated in liquid nitrogen to obtain the extract

Table 3. Nitrogen $(\mathrm{N})$ and Phosphorus $(\mathrm{P})$ measured at the end of 80 days of shoots $(\mathrm{S})$ and roots $(\mathrm{R})$ of $O$. basilicum 'genovese' as a function of different formulations of MS medium and photoperiods.

\begin{tabular}{|c|c|c|c|c|}
\hline \multirow{3}{*}{ Treatments } & \multicolumn{4}{|c|}{ g. $\mathrm{Kg}^{-1}$} \\
\hline & \multicolumn{2}{|c|}{$\mathrm{N}$} & \multicolumn{2}{|c|}{$\mathrm{P}$} \\
\hline & $B$ & $R$ & $B$ & $R$ \\
\hline T1 & $54.63 \pm 0.04^{\mathrm{abc} *}$ & $39.87 \pm 2.14^{\mathrm{ab}}$ & $2.50 \pm 0.39^{\mathrm{a}}$ & $2.55 \pm 0.23^{\mathrm{a}}$ \\
\hline $\mathrm{T} 2$ & $50.94 \pm 4.39^{\mathrm{bc}}$ & $45.90 \pm 0.49^{\mathrm{a}}$ & $3.04 \pm 0.47^{\mathrm{a}}$ & $2.27 \pm 0,09^{a}$ \\
\hline T3 & $51.39 \pm 0.41^{b c}$ & $36.77 \pm 2.26^{\mathrm{ab}}$ & $2.60 \pm 0.06^{a}$ & $1.99 \pm 0.17^{\mathrm{ab}}$ \\
\hline T4 & $64.40 \pm 0.21^{\mathrm{a}}$ & $41.34 \pm 7.73^{\mathrm{a}}$ & $2.92 \pm 0.11^{\mathrm{a}}$ & $2.63 \pm 0.09^{a}$ \\
\hline T5 & $44.87 \pm 1.55^{c}$ & $25.76 \pm 2.93^{\mathrm{b}}$ & $2.75 \pm 0.06^{\mathrm{a}}$ & $1.29 \pm 0.14^{b}$ \\
\hline T6 & $58.06 \pm 5.23^{\mathrm{ab}}$ & $39.21 \pm 2.37^{\mathrm{ab}}$ & $3.17 \pm 0.57^{\mathrm{a}}$ & $1.60 \pm 0.21^{b c}$ \\
\hline
\end{tabular}

*Means followed by the same letter in the column do not differ by Tukey's test 5\%. T1 -24 h light; T2 - $12 \mathrm{~h}$ light $+12 \mathrm{~h}$ dark; T3 $16 \mathrm{~h}$ light $+8 \mathrm{~h}$ dark - (T1: T3 MS 100\%, sucrose 30.0 g. $\mathrm{L}^{-1}$, agar $\left.6.5 \mathrm{~g} . \mathrm{L}^{-1}\right)$; T4 -24 h light; T5 - 12h light + $12 \mathrm{~h}$ dark; T6 - 16 h light + $8 \mathrm{~h}$ dark - (T4:T6 MS 100\%, sucrose $30.0 \mathrm{~g} . \mathrm{L}^{-1}$ agar; $6.5 \mathrm{~g} . \mathrm{L}^{-1}$;BAP $0.4 \mathrm{~g} . \mathrm{L}^{-1}$ and NAA $\left.0.2 \mathrm{~g} . \mathrm{L}^{-1}\right)$.

Table 4. Total antioxidant activity from 2.2-difenil-1-picrilhidrazil (DPPH) obtained after 80 days of fresh leaves 0 . basilicum 'genovese' as a function of different formulations of MS medium and photoperiods.

\begin{tabular}{cc}
\hline Treatments & Total antioxidant activity (\%) \\
\hline T1 & $5.91 \pm 1.84^{\mathrm{b}^{*}}$ \\
T2 & $6.37 \pm 2.24^{\mathrm{b}}$ \\
T3 & $4.41 \pm 1.32^{\mathrm{b}}$ \\
T4 & $4.41 \pm 1.58^{\mathrm{b}}$ \\
T5 & $1.94 \pm 1.44^{\mathrm{b}}$ \\
T6 & $17.29 \pm 4.48^{\mathrm{a}}$ \\
\hline
\end{tabular}

* Means followed by the same letter in the column do not differ by Tukey's test 5\%.T1 -24 h light; T2 - 12h light + $12 \mathrm{~h}$ dark; T3 - $16 \mathrm{~h}$ light +8 h dark - (T1: T3 MS 100\%, sucrose 30.0 g. $\mathrm{L}^{-1}$, agar 6.5 g. $\left.\mathrm{L}^{-1}\right) ; \mathrm{T} 4-24 \mathrm{~h}$ light; T5 - 12h light $+12 \mathrm{~h}$ dark; T6 - 16 h light + 8 h dark - (T4:T6 MS 100\%, sucrose 30.0 g. $\mathrm{L}^{-1}$; agar $6.5 \mathrm{~g} \cdot \mathrm{L}^{-1}$;BAP $0.4 \mathrm{~g} \cdot \mathrm{L}^{-1}$ and NAA $0.2 \mathrm{~g} . \mathrm{L}^{-1}$ ).

Table 5. Number of leaves (NL), shoots (NS), length of shoots (LS), fresh mass shoots (FMS), dry mass shoots (DMS), fresh root mass (FRM) dry root mass (DRM) and chlorophyll (CL) of $O$. basilicum 'genovese' as a function of different concentrations of potassium iodide.

\begin{tabular}{ccccc}
\hline $\begin{array}{c}\text { Treatments } \\
(\mu \mathrm{M})\end{array}$ & $\mathrm{NL}$ & $\mathrm{NS}$ & LS $(\mathrm{mm})$ & FMS $(\mathrm{g})$ \\
\hline 0 & $24.69 \pm 1.03^{\mathrm{a}^{\mathrm{a}}}$ & $0.75 \pm 0.96^{\mathrm{a}}$ & $76.86 \pm 10.60^{\mathrm{a}}$ & $4.90 \pm 0.37^{\mathrm{a}}$ \\
25 & $20.56 \pm 6.20^{\mathrm{ab}}$ & $0.25 \pm 0.50^{\mathrm{a}}$ & $74.30 \pm 21.03^{\mathrm{a}}$ & $2.19 \pm 1.05^{\mathrm{b}}$ \\
50 & $14.53 \pm 2.69^{\mathrm{b}}$ & $1.00 \pm 0.00^{\mathrm{a}}$ & $79.91 \pm 14.14^{\mathrm{a}}$ & $2.15 \pm 0.79^{\mathrm{b}}$ \\
75 & $13.89 \pm 4.66^{\mathrm{b}}$ & $0.25 \pm 0.50^{\mathrm{a}}$ & $59.66 \pm 6.56^{\mathrm{a}}$ & $2.48 \pm 0.29^{\mathrm{b}}$ \\
100 & $15.57 \pm 3.56^{\mathrm{b}}$ & $0.50 \pm 1.00^{\mathrm{a}}$ & $75.24 \pm 6.32^{\mathrm{a}}$ & $2.70 \pm 0.46^{\mathrm{b}}$ \\
\hline Treatments & $\mathrm{DMS}(\mathrm{g})$ & $\mathrm{FRM} \mathrm{(g)}$ & $\mathrm{DMR}(\mathrm{g})$ & $\mathrm{CL}$ \\
$(\mu \mathrm{M})$ & $0.37 \pm 0.04^{\mathrm{a}}$ & $3.86 \pm 0.82^{\mathrm{a}}$ & $0.15 \pm 0.03^{\mathrm{a}}$ & $19.53 \pm 2.47^{\mathrm{a}}$ \\
0 & $0.27 \pm 0.12^{\mathrm{a}}$ & $3.12 \pm 1.36^{\mathrm{a}}$ & $0.12 \pm 0.04^{\mathrm{a}}$ & $22.51 \pm 1.87^{\mathrm{a}}$ \\
25 & $0.29 \pm 0.17^{\mathrm{a}}$ & $2.82 \pm 0.99^{\mathrm{a}}$ & $0.11 \pm 0.03^{\mathrm{a}}$ & $23.32 \pm 1.91^{\mathrm{a}}$ \\
50 & $0.22 \pm 0.05^{\mathrm{a}}$ & $2.23 \pm 0.68^{\mathrm{a}}$ & $0.09 \pm 0.02^{\mathrm{a}}$ & $22.78 \pm 0.89^{\mathrm{a}}$ \\
75 & $0.19 \pm 0.04^{\mathrm{a}}$ & $2.00 \pm 0.72^{\mathrm{a}}$ & $0.09 \pm 0.04^{\mathrm{a}}$ & $23.30 \pm 3.40^{\mathrm{a}}$ \\
\hline 100 &
\end{tabular}

*Means followed by the same letter in the column do not differ by Tukey's test $5 \%$

Table 6. Nitrogen (N), potassium (K), Calcium (Ca) and Magnesium (Mg) measured at the end of 80 days of shoots (S) and roots (R) of $O$. basilicum 'genovese' as a function of different concentrations of potassium iodide.

\begin{tabular}{|c|c|c|c|c|c|c|c|c|}
\hline \multirow{3}{*}{$\begin{array}{l}\text { Treatments } \\
\qquad(\mu \mathrm{M})\end{array}$} & \multicolumn{8}{|c|}{ g. $\mathrm{Kg}^{-1}$} \\
\hline & \multicolumn{2}{|c|}{$\mathrm{N}$} & \multicolumn{2}{|c|}{ K } & \multicolumn{2}{|c|}{$\mathrm{Ca}$} & \multicolumn{2}{|c|}{$\mathrm{Mg}$} \\
\hline & $S$ & $\mathrm{R}$ & $S$ & $R$ & $S$ & $\mathrm{R}$ & $S$ & $R$ \\
\hline \multirow[t]{2}{*}{0} & $48.74 \pm 4.18^{\mathrm{a}^{*}}$ & $38.81 \pm 0.59^{b}$ & $15.13 \pm 4.75^{\mathrm{a}}$ & $12.19 \pm 1.78^{\mathrm{a}}$ & $3.16 \pm 0.43^{a}$ & $1.44 \pm 0.21^{\mathrm{a}}$ & $0.38 \pm 0.05^{a}$ & $0.27 \pm 0.01^{a}$ \\
\hline & & & & 1651 & & & & \\
\hline
\end{tabular}




\begin{tabular}{ccccccccc}
\hline 25 & $41.14 \pm 2.06^{\mathrm{a}}$ & $38.52 \pm 1.47^{\mathrm{b}}$ & $10.51 \pm 0.59^{\mathrm{a}}$ & $10.93 \pm 3.56^{\mathrm{a}}$ & $3.17 \pm 0.03^{\mathrm{a}}$ & $1.73 \pm 0.12^{\mathrm{a}}$ & $0.33 \pm 0.0^{\mathrm{a}}$ & $0.25 \pm 0.07^{\mathrm{a}}$ \\
50 & $44.30 \pm 1.89^{\mathrm{a}}$ & $46.18 \pm 1.52^{\mathrm{a}}$ & $14.30 \pm 0.0^{\mathrm{a}}$ & $10.51 \pm 1.78^{\mathrm{a}}$ & $3.90 \pm 0.11^{\mathrm{a}}$ & $1.79 \pm 0.20^{\mathrm{a}}$ & $0.41 \pm 0.05^{\mathrm{a}}$ & $0.30 \pm 0.03^{\mathrm{a}}$ \\
75 & $45.04 \pm 0.54^{\mathrm{a}}$ & $44.55 \pm 1.32^{\mathrm{a}}$ & $14.71 \pm 0.59^{\mathrm{a}}$ & $10.51 \pm 0.59^{\mathrm{a}}$ & $3.54 \pm 0.31^{\mathrm{a}}$ & $1.90 \pm 0.98^{\mathrm{a}}$ & $0.38 \pm 0.017^{\mathrm{a}}$ & $0.35 \pm 0.03^{\mathrm{a}}$ \\
100 & $46.47 \pm 6,78^{\mathrm{a}}$ & $47.95 \pm 1.10^{\mathrm{a}}$ & $14.71 \pm 0.59^{\mathrm{a}}$ & $13.03 \pm 5.35^{\mathrm{a}}$ & $3.71 \pm 0.07^{\mathrm{a}}$ & $2.24 \pm 0.49^{\mathrm{a}}$ & $0.43 \pm 0.035^{\mathrm{a}}$ & $0.44 \pm 0.15^{\mathrm{a}}$ \\
\hline
\end{tabular}

* Means followed by the same letter in the column do not differ by Tukey's test $5 \%$.

Table 7. Total antioxidant activity from 2.2-difenil-1-picrilhidrazil (DPPH) obtained after 80 days of fresh leaves 0 . basilicum 'genovese' as a function of different concentrations of potassium iodide.

\begin{tabular}{cc}
\hline $\begin{array}{c}\text { Treatments } \\
(\mu \mathrm{M})\end{array}$ & Total antioxidant activity (\%) \\
\hline 0 & $14.43 \pm 0.15^{\mathrm{a}^{*}}$ \\
25 & $17.26 \pm 2.68^{\mathrm{a}}$ \\
50 & $14.95 \pm 0.78^{\mathrm{a}}$ \\
75 & $13.6 \pm 1.73^{\mathrm{a}}$ \\
100 & $17.11 \pm 1.34^{\mathrm{a}}$ \\
\hline
\end{tabular}

* Means followed by the same letter in the column do not differ by Tukey's test $5 \%$

were performed in triplicates $(515 \mathrm{~nm}$ ) until stabilization (30 in $30 \mathrm{~min}$ ) using a Beckman 640 B spectrophotometer. Results are expressed as a percentage of free radical sequestration (\% SRL), according to the following equation: $\% \mathrm{SRL}=\frac{(\mathrm{CA}-\mathrm{AS})}{\mathrm{CA}} \times 100$

Where; $\mathrm{Ca}=$ control absorbance, and As $=$ absorbance of the sample.

\section{Enzyme analyses}

Plant extract was produced using $200 \mathrm{mg}$ of fresh leaves macerated in liquid nitrogen (Bonacina et al., 2017) to measure three antioxidant enzymes SOD (EC 1.15.1.1) was measured by inhibition of the photoreduction of nitroblue tetrazolium (NBT) and was expressed as $\mathrm{U}$ SOD g ${ }^{-1} \mathrm{MF}$ per min (Giannopolitis and Ries, 1977); CAT (EC 1.11.1.6) was measured according to the protocol of Havir and $\mathrm{McHale}$ (1987) using the molar extinction coefficient of $36 \mathrm{M}^{-1}$ per min and expressed in mmol $\mathrm{H}_{2} \mathrm{O}_{2} \mathrm{~g}^{-1} \mathrm{MF}$ per min (Anderson et al., 1995); and APX (EC 1.11.1.11) activity was measured according to the protocol of de Nakano and Asada (1981) by the degradation of $\mathrm{H}_{2} \mathrm{O}_{2}$ to $290 \mathrm{~nm}$ within $1 \mathrm{~min}$, quantified using the molar extinction coefficient of $2.8 \mathrm{mM}^{-1}$ percmand was expressed as mmol ascorbic acid $\mathrm{g}^{-1} \mathrm{MF}$ per min. Analyses of both experiments were performed after 80 days. Enzyme activity was measured using flat-bottomed 96-well plates and with a UV-VIS spectrophotometer (Espectra Max Plus San Jose, US) with the software SoftMax Pro 6.5.1 (Molecular Devices San Jose, US).

\section{Statistical analyses}

Both experiments were set up in a completely randomized design with five replicates, and each replicate comprised six flasks with four seeds. Normal distribution of biometric data and antioxidant activity was tested using a Shapiro-Wilk test. Data that significantly deviated from normal distribution were subjected to a Kruskal-Wallis test using the software Assistat version 7.7 (Silva and Azevedo, 2016). All other data were tested using an analysis of variance, and means were compared using a Tukey's test with the software SISVAR 5.6 (Ferreira, 2011). Statistical significance is reported at $\mathrm{p}(\leq$ 0.05).

\section{Conclusions}

Growth of seedlings of $O$. basilicum 'Genovese' was stable at photoperiods of $16 \mathrm{~h}$ and $24 \mathrm{~h}$, however, growth regulators exerted a beneficial effect. Antioxidant defense mechanisms were important to ameliorate adverse effects. Antioxidant activity and APX concentrations produced higher average values in the treatments with $16 \mathrm{~h}$ light and with addition of growth regulators.

Additional $\mathrm{K}$ supplementation showed no beneficial effect on growth but led to a decrease in the number of leaves and in shoot mass. CAT showed higher activity at higher $\mathrm{KI}$ concentrations, therefore enzymatic mechanisms seem to be important for the control of free radicals since antioxidant activity did not differ between treatments.

\section{Acknowledgments}

We would like to thank the Coordenação de Aperfeiçoamento de Pessoal de Nível Superior (CAPES) $n^{\circ}$ 001 and Conselho Nacional de Desenvolvimento Científico $e$ Tecnológico (CNPq) for funding this work. And Universidade Paranaense (UNIPAR) for financial support.

\section{References}

Adams SR, Langton, FA (2005) Photoperiod and plant growth: a review. J Hortic Sci Biotech. 80:2-10.

Aghaei K, Ehsanpour AA, Komatsu S (2009) Potato responds to salt stress by increased activity of antioxidant enzymes. J Integr Plant Biol. 5:1095-1103.

Ahanger MA, Agarwal RM (2017) Potassium up-regulates antioxidant metabolism and alleviates growth inhibition under water and osmotic stress in wheat (Triticum aestivum L). Protoplasma. 254:1471-1486.

Alves GAC, Campos FR, Bertoncelli DJ, Furlan FF, Freiria GH, Faria RT (2016) Development of Cattleya loddigesii Lindley in vitro with doses of potassium silicate. Agrop Tec. 37:81-97.

Alvarez MA (2014) Plant biotechnology for health: from secondary metabolites to molecular farming, 1rd edn.Springuer.New York.

Amaral-Baroli A, Lago JHG, Almeida CV, Almeida M, Scotti MT, Leone GF, Sartorelli P (2016) Variability in essential oil composition produced by micropropagated (in vitro), acclimated (ex vitro) and in-field plants of Ocimum basilicum (Lamiaceae). Ind Crop Prod. 86:180-185.

Bonacina C, Trevizan CB, Stracieri J, Santos TB, Gonçalves JE, Gazim ZC, Souza SGH (2017) Changes in growth, oxidative metabolism and essential oil composition of lemon balm 
('Melissa officinalis' L.) subjected to salt stress. Aus J Crop Sci. 11:1665-1674.

Cassells AC (2012) Pathogen and biological contamination management in plant tissue culture: phytopathogens, vitro pathogens, and vitro pests. In Plant Cell Cult. Prot 877:57-80.

Demidchik V (2015) Mechanisms of oxidative stress in plants: from classical chemistry to cell biology. Environ Exp Bot. 109:212-228.

Ferreira DF (2011) Sisvar: a computer statistical analysis system. Ciência Agrot. 35:1039-1042.

Fukaki H, Tasaka M (2009) Hormone interactions during lateral root formation. Plant Mol Bio-I 69:437-439.

Furlan MR, Aoyama EM, Indriunas A, Mauro C (2013) Leaf Anatomy of Ocimum basilicum L. "Genovese" (Lamiaceae). Rev Fitos. 7:231-235.

George EF, Hall MA, Klerk GJ (2008) Plant propagation by tissue culture, 1rd edn. Springuer. Netherland.

Giannopolitis CN, Ries SK (1977) Superoxide dismutases: I. Occurrence in higher plants. Plant Physiol. 59:309-314

Gill SS, Tuteja N (2010) Reactive oxygen species and antioxidant machinery in abiotic stress tolerance in crop plants. Plant Physiol Biochem. 48:909-930.

Guo W, Nazim H, Liang Z, Yang D (2016) Magnesium deficiency in plants: an urgent problem. The CropJ. 4:83-91.

Havir EA, McHale NA (1987) Biochemical and developmental characterization of multiple forms of catalase in tobacco leaves. Plant Physiol. 84:450-455.

Hussain Al, Anwar F, Sherazi STH, Przybylski R (2008) Chemical composition, antioxidant and antimicrobial activities of basil (Ocimum basilicum) essential oils depends on seasonal variations. Food Chem. 108:986-995.

Javanmardi J, Stushnoff C, Locke E, Vivanco J M (2003) Antioxidant activity and total phenolic content of Iranian Ocimum accessions. Food Chem. 83:547-550.

Jo EA, Tewari RK, Hahn EJ, Paek KY (2008) Effect of photoperiod and light intensity on in vitro propagation of Alocasia amazonica. Plant Biotechnol Rep. 2:207-212.

Kiferle C, Maggini R, Pardossi A (2013) Influence of nitrogen nutrition on growth and accumulation of rosmarinic acid in sweet basil (Ocimum basilicum L.) grown in hydroponic culture.Aust J Crop Sci 7:321-327

Kurilčik A, Dapkūnienè $S$, Kurilčik G, Žilinskaitė $S$, Žukauskas A, Duchovskis $P$ (2008) Effect of the photoperiod duration on the growth of Chrysanthemum plantlets in vitro. Sci Works Lith Inst Hort Lith Univ Agric Sodininkyste Ir Darzyninkyste. 27:3943.

Magalhães HM, Brandão TM, Stracieri J, Jesus HF, Mendes DST, Pasqual M (2017) Evaluating chemical composition of Butia capitata pulp among various populations and locations using multivariate analysis. Afr J Biotechnol. 16:1902-1910.

Mahmoud G I (2013) Biological effects, antioxidant and anticancer activities of marigold and basil essential oils. J Med Plants Res. 7:561-572.

Makri O, Kintzios S (2008) Ocimum sp. (Basil): botany, cultivation, pharmaceutical properties, and biotechnology. J Herbs Spices Med Plants. 13:123-150.

Malavolta E (1980) Elementos de nutrição mineral de plantas, Agronômica Ceres. São Paulo.

Malvi UR (2011) Interaction of micronutrients with major nutrients with special reference to potassium. Karn J Agric Sci. 24:106-109.

Matkowski A (2008) Plant in vitro culture for the production of antioxidants-a review. BiotechnolAdv 26:548-560

Motte H, Vereecke D, Geelen D, Werbrouck S (2014) The molecular path to in vitro shoot regeneration. Biotechnol Adv. 32:107-121.
Murashige T, Skoog F (1962) A revised medium for rapid growth and bio assays with tobacco tissue cultures. Physiol Plantarum. 15:473-497.

Nakano Y, Asada K (1981) Hydrogen peroxide is scavenged by ascorbate specific peroxidase in spinach chloroplasts. Plant Cell Physiol. 22:867-880.

Ncube B, Finnie J F, Van Staden J (2012) Quality from the field: the impact of environmental factors as quality determinants in medicinal plants. S Afr J Bot. 82:11-20.

Noctor G, Reichheld JP, Foyer CH (2018) ROS-related redox regulation and signaling in plants. Seminars Cell Dev Biol. 80:3-12.

Pagano I, Sánchez-Camargo ADP, Mendiola JA, Campone L, Cifuentes A, Rastrelli L, Ibañez E (2018) Selective extraction of high-value phenolic compounds from distillation wastewater of basil (Ocimumbasilicum L.) by pressurized liquid extraction. Electrophoresis. 39:1884-1891.

Patel H, Krishnamurthy R (2013) Elicitors in plant tissue culture. J Pharmacogn Phytochemi. 2:60-65.

Rietra RP, Heinen M, Dimkpa CO, Bindraban PS (2017) Effects of nutrient antagonism and synergism on yield and fertilizer use efficiency. Commun Soil Sci Plant Analysis. 48:1895-1920.

Rufino M, Fernandes F, Alves R, Debrito E (2009) Free radicalscavenging behaviour of some north-east Brazilian fruits in a DPPH system. Food Chem. 114:693-695.

Saxena C, Samantaray S, Rout GR, Das P (2000) Effect of auxins on in vitro rooting of Plumbagozeylanica: peroxidase activity as a marker for root induction. Biol Plantarum. 43:121-124.

Silva FJ, Nascimento AB, Barbosa LN, Magalhães HM (2017) 'In vitro' cultivation of purple basil 'Ocimum basilicum'L. 'red rubin' at different levels of salts, charcoal, sucrose and potassium iodine. Aust J Crop Sci. 11:1137.

Silva FAS, Azevedo CAV (2016) The Assistat Software Version 7.7 and its use in the analysis of experimental data.

Suppakul P, Miltz J, Sonneveld K, Bigger SW (2003) Antimicrobial properties of basil and its possible application in food packaging. J Agric Food Chem. 51:3197-3207.

Tenore GC, Campiglia P, Ciampaglia R, Izzo L, Novellino E (2017) Antioxidant and antimicrobial properties of traditional green and purple "Napoletano" basil cultivars (Ocimum basilicum L.) from Campania region (Italy). Nat Product Research. 31:20672071.

Trettel JR, Gazim Z C, Goncalves JE, Stracieri J, Magalhães HM (2018b) Effects of copper sulphate $\left(\mathrm{CuSO}_{4}\right)$ elicitation on the chemical constitution of volatile compounds and the in vitro development of Basil. Sci Hortic. 234:19-26.

Trettel JR, Gazim Z C, Gonçalves JE, Stracieri J, Magalhães H M (2017) Volatile essential oil chemical composition of basil (Ocimum basilicum L.'Green') cultivated in a greenhouse and micropropagated on a culture medium containing copper sulfate. In Vitro Cellular Dev Biol - Plant. 53:631-640.

Trettel JR, Nascimento AB, Barbosa LN, Magalhães HM (2018a) In vitro growth of genovese basil in response to different concentrations of salts and interaction of sucrose and activated carbon. J Agr Sci. 10:1-11.

Vaillant V, Bade P, Constant C (2005) Photoperiod affects the growth and development of yam plantlets obtained by in vitro propagation. Biol Plantarum. 49:355-359.

Velez-Ramirez Al, Van leperen W, Vreugdenhil D, Millenaar FF (2011) Plants under continuous light. Trends Plant Sci. 16:310318.

White PJ, Broadley MR (2003) Calcium in plants. Ann Bot. 92:487-511.

Zuzarte MR, Dinis AM, Cavaleiro C, Salgueiro LR, Canhoto JM (2010) Trichomes, essential oils and in vitro propagation of Lavandula pedunculata (Lamiaceae). Ind Crops Prod. 32:580587. 
